\title{
RELASI DENGAN TEMAN, MODE KOMUNIKASI, DAN SUBJECTIVE WELL- BEING ANAK DAN REMAJA PADA TAHUN KEDUA PANDEMI COVID-19
}

\author{
Ihsana Sabriani Borualogo \\ Fakultas Psikologi, Universitas Islam Bandung \\ Jalan Tamansari No. 1, Bandung, 40116 \\ Email: ihsana.sabriani@unisba.ac.id
}

\begin{abstract}
ABSTRAK
Pandemi COVID-19 telah memasuki tahun kedua dan membatasi relasi sosial anak dan remaja dengan temantemannya. Penelitian ini bertujuan menguji persepsi anak dan remaja mengenai relasinya dengan teman di masa pandemi terhadap subjective well-being (SWB) serta menguji mode komunikasi yang digunakan oleh anak dan remaja untuk berinteraksi dengan teman yang berperan terhadap SWB. Partisipan penelitian ini $(N=1,657 ; 45.1 \%$ perempuan; 54.9\% laki-laki) adalah anak dan remaja usia 10-18 tahun $(M=14.85)$ di Jawa Barat. Pengambilan data dilakukan secara dalam jaringan (daring) menggunakan Google Form dengan teknik sampling convenience. SWB diukur menggunakan Children's Worlds Subjective Well-Being Scale 5 items (CW-SWBS5), sedangkan persepsi mengenai relasi dengan teman diukur menggunakan alat ukur relasi dengan teman dari Children's Worlds. Data dianalisis menggunakan regresi linear berganda dan analisis deskriptif menggunakan ANOVA. Hasil menunjukkan persepsi anak bahwa mereka memiliki teman yang cukup, teman yang biasanya baik, dan teman yang memberikan dukungan saat anak memiliki masalah, berkontribusi positif terhadap SWB anak, di mana skor SWB secara signifikan lebih tinggi dibandingkan skor SWB anak yang mempersepsi tidak memiliki cukup teman, teman biasanya tidak baik, dan teman tidak memberikan dukungan saat anak memiliki masalah. Penggunaan mode komunikasi voice call, Twitter, video call, dan Instagram yang digunakan untuk berinteraksi dengan teman pada tahun kedua pandemi dapat memprediksi SWB anak dan remaja. Guna mempertahankan tingkat SWB anak dan remaja di masa pandemi, hendaknya orang tua mengizinkan anak tetap menjalin relasi sosial dengan teman-temannya menggunakan mode komunikasi daring di masa pembatasan jarak sosial di bawah supervisi orang tua.
\end{abstract}

Kata kunci: anak; mode komunikasi; pandemi COVID-19; relasi sosial; remaja; subjective well-being

\section{RELATIONSHIP WITH FRIENDS, MODES OF COMMUNICATION, AND SUBJECTIVE WELL-BEING OF CHILDREN AND ADOLESCENTS IN THE SECOND YEAR OF PANDEMIC}

\begin{abstract}
The COVID-19 pandemic has lasted for two years and has limited social relationships with friends. This study aims to examine children's and adolescents' perceptions of their relationship with friends during the pandemic on subjective well-being (SWB). The study further aims to examine the contribution of the modes of communication used by children and adolescents to their SWB. The participants of this study $(N=1,657 ; 45.1 \%$ girls; $54.9 \%$ boys) were children and adolescents aged 10-18 years $(M=14.85)$ in West Java. Data were collected using Google Form with convenience sampling. SWB was measured using the Children's Worlds Subjective Well-Being Scale 5 items (CW-SWBS5). Perceptions of relationships with friends were measured using Children's Worlds' relationship with friends' instrument. Data were analyzed using multiple linear regression and descriptive analysis using ANOVA. The results showed that children and adolescents who perceive themselves as having enough friends and perceive their friends as nice and supportive when they face problems contribute positively to their SWB. Their SWB scores are significantly higher than SWB scores of children and adolescents who perceive themselves as not having enough friends and don't perceive their friends as nice and support them when they have problems. Specific modes of communication (voice call, Twitter, video call, and Instagram) they used to stay in contact with friends during the pandemic can predict their SWB. To maintain children's SWB during the pandemic, parents should allow their children to stay in contact with friends using online communication modes under parental supervision during social distancing.
\end{abstract}

Keywords: adolescents; children; COVID-19 pandemic; modes of communication; social relationship; subjective well-being 


\section{PENDAHULUAN}

Pada 11 Maret 2020, World Health Organization (WHO) mendeklarasikan COVID-19 sebagai pandemi karena efek global yang ditimbulkannya terhadap kesehatan masyarakat dunia (Ducharme, 2020). Hingga kini, COVID-19 telah memasuki tahun kedua sebagai pandemi. Per tanggal 10 November 2021, Pemerintah Indonesia melaporkan sejumlah 4,249,323 orang terkonfirmasi COVID19, sebanyak 143,592 korban meninggal dunia akibat COVID-19, dan 4,096,194 dinyatakan sembuh dari penyakit ini (WHO, 2021). Pandemi COVID-19 ternyata tidak hanya memberikan efek signifikan bagi kesehatan masyarakat dunia, namun juga memberikan efek terhadap aspek ekonomi, sosial, dan psikologis bagi masyarakat (Gandhawangi, 2021; Purwanto, 2021).

Karena penyebaran yang cepat dari virus Corona, sejumlah negara menetapkan aturan lockdown dengan tidak mengizinkan warganya bepergian meninggalkan rumah sehingga membatasi interaksi sosial mereka. Indonesia juga menerapkan aturan ini melalui Pembatasan Sosial Berskala Besar (PSBB) maupun Pemberlakuan Pembatasan Kegiatan Masyarakat (PPKM) (Permatasari, 2021). Demikian pula dengan kegiatan belajar di sekolah yang dilakukan melalui Pembelajaran Jarak Jauh (PJJ), di mana siswa mengikuti pembelajaran secara dalam jaringan (daring). Salah satu konsekuensi dari PJJ adalah terbatasnya kesempatan siswa untuk dapat bertemu dengan teman-teman sekolahnya.

Walaupun aturan pembatasan jarak sosial ini dilakukan untuk tujuan kesehatan masyarakat, namun berbagai studi menunjukkan bahwa pembatasan jarak sosial ini menurunkan kualitas hidup, bahkan mengganggu kesehatan mental individu. Sebuah studi di Singapura menunjukkan terjadinya penurunan signifikan pada nilai rerata kepuasan hidup pada orang dewasa (Cheng et al., 2020). Studi di Australia juga menunjukkan bahwa terjadi penurunan keterhubungan sosial pada orang dewasa di masa pandemi (Khor et al., 2020). Studi di Amerika menunjukkan terjadinya peningkatan depresi dan gangguan kecemasan umum pada masa pembatasan jarak sosial (Marroquín et al., 2020). Beberapa studi internasional menunjukkan bahwa tidak hanya orang dewasa, tetapi anak-anak juga mengalami penurunan kepuasan hidup di masa pandemi (Engel de Abreu et al., 2021; Kirsch et al., 2020; Mitra et al., 2021).

Manusia memiliki kebutuhan yang sangat kuat untuk selalu berinteraksi dan menjalin relasi sosial dengan manusia lainnya. Menurut Dimmock et al. (2021), di antara berbagai tantangan perubahan gaya hidup di masa pandemi, salah satu yang dirasakan paling menyulitkan adalah keharusan menjaga jarak sosial dari teman dan keluarga. Sebuah studi yang dilakukan oleh Borualogo dan Casas (2021a) terhadap 1,474 anak dan remaja di Indonesia yang pengambilan datanya dilakukan pada Mei hingga Juli 2020 menunjukkan bahwa anak dan remaja merasa tidak puas dengan kontak yang mereka lakukan dengan teman di masa pembatasan jarak sosial karena mereka tidak dapat bertemu secara langsung. Studi lain yang dilakukan oleh Borualogo dan Casas (2021b) juga menunjukkan terjadinya penurunan signifikan skor subjective well-being (SWB) anak dan remaja dibandingkan pada masa sebelum COVID-19.

Subjective well-being (SWB) didefinisikan sebagai evaluasi subjektif individu atas kepuasannya akan kehidupan yang dinilai berjalan sesuai harapan (Diener et al., 2015). Diener et al. (2015) menjelaskan adanya tiga komponen SWB, yaitu komponen kognitif (evaluasi individu mengenai kepuasan hidupnya secara umum), komponen afek positif (perasaan bahagia dan menyenangkan), dan komponen afek negatif (perasaan tidak menyenangkan, sedih, dan marah). Penelitian-penelitian SWB anak lebih difokuskan pada komponen kognitif dengan mengukur kepuasan hidup anak (Savahl et al., 2021) karena komponen kognitif dinilai lebih stabil dibandingkan komponen afek (Rees, 2018).

Children's Worlds merupakan pionir dalam melakukan studi mengenai SWB anak dengan mengukur beberapa domain dalam kehidupan anak (Rees et al., 2020). Salah satu domain dalam kehidupan anak adalah teman dan bagaimana anak mempersepsi pertemanannya (Rees et al., 2020). Kepuasan dalam hidup anak terkait dengan relasi yang dibangun oleh anak dengan orang-orang di sekitarnya, termasuk dengan teman (Mínguez, 2020; Savahl et al., 2020). Goswami (2012) menjelaskan bahwa relasi positif dengan teman merupakan salah satu faktor yang memberikan efek bagi SWB anak.

Kebutuhan untuk tetap menjalin relasi sosial di masa pandemi mendorong individu untuk menggunakan media sosial berbasis internet untuk mempertahankan relasi sosial (Dimmock et al., 2021). Wantiknas (n.d.) melaporkan terjadinya peningkatan penggunaan WhatsApp dan Instagram sebesar 40\% selama pandemi. Hasil survei Asosiasi Penyelenggara Jasa Internet Indonesia (APJII) 
menunjukkan bahwa penetrasi internet di Indonesia selama pandemi mencapai $73.7 \%$, di mana $29.3 \%$ responden menggunakannya untuk berkomunikasi dan $24.7 \%$ menggunakannya untuk aktivitas di media sosial (Prasetyani, 2021). Berdasarkan data tersebut, terungkap tingginya penggunaan mode komunikasi berbasis internet untuk mempertahankan relasi sosial di masa pandemi. Meski demikian, data tersebut belum dapat menjelaskan mengenai penggunaan mode komunikasi tersebut pada kelompok anak dan remaja untuk relasi sosialnya dengan teman.

Studi internasional menunjukkan bahwa relasi dengan teman memiliki kontribusi terhadap SWB anak (Goswami, 2012), namun belum dilakukan kajian mengenai relasi dengan teman pada masa pandemi dan kontribusinya terhadap SWB anak. Penelitian di Indonesia juga belum melakukan kajian terhadap peran relasi dengan teman terhadap SWB anak, terutama pada masa pandemi. Padahal, relasi dengan teman merupakan salah satu faktor yang berkontribusi terhadap SWB anak dan remaja. Selain itu, pada masa pandemi terjadi pembatasan relasi sosial dengan teman karena adanya PSBB dan PPKM. Oleh karena itu, penelitian ini dilakukan untuk menguji kontribusi dari persepsi anak dan remaja mengenai relasinya dengan teman di masa pandemi terhadap SWB serta menguji mode komunikasi yang digunakan oleh anak dan remaja untuk berinteraksi dengan teman pada tahun kedua COVID-19 yang berperan terhadap SWB. Melalui penelitian ini, diharapkan akan diperoleh pengetahuan baru yang akan mengisi kesenjangan informasi mengenai relasi dengan teman dan SWB anak. Dengan pengetahuan baru ini, dapat meningkatkan kesadaran mengenai pentingnya relasi dengan teman sebaya di masa pandemi dan kontribusinya terhadap SWB anak dan remaja.

Adapun pertanyaan penelitian yang akan dijawab dalam penelitian ini adalah:

1. Bagaimana kontribusi dari relasi dengan teman terhadap SWB anak dan remaja di masa pandemi?

2. Mode komunikasi seperti apa yang memberikan kontribusi bagi SWB anak di masa pandemi?

\section{METODE}

Desain penelitian ini adalah survei dengan variabel bebas persepsi mengenai teman dan mode komunikasi yang digunakan di masa pandemi, dan variabel terikat subjective well-being (SWB). Penelitian ini telah mendapatkan izin etik dari Konsorsium Psikologi Ilmiah Nusantara (K-PIN) dengan nomor 001/2021 Etik/KPIN. Pengumpulan data dilakukan pada masa pandemi COVID-19 antara bulan Maret hingga Mei 2021 menggunakan Google Form secara daring. Pada Google Form, disertakan informed consent yang perlu diisi oleh orang tua untuk menyatakan mengizinkan anaknya menjadi partisipan penelitian. Jika orang tua telah mengizinkan, maka orang tua akan memberikan Google Form tersebut kepada anaknya untuk diisi oleh anak. Kepada anak juga diinformasikan melalui Google Form bahwa mereka boleh memilih untuk ikut berpartisipasi ataupun tidak dan boleh mengisi ataupun tidak. Jika anak menyatakan bersedia, mereka dapat menjawab pertanyaan-pertanyaan yang disajikan di dalam Google Form dan mengirimkannya secara otomatis kepada peneliti ketika mereka telah selesai mengerjakannya.

Partisipan penelitian ini adalah anak dan remaja usia 10-18 tahun $(N=1,657 ; 45.1 \%$ perempuan; 54.9\% laki-laki) tinggal di Jawa Barat. Karakteristik sampel disajikan pada Tabel 1. Teknik sampling yang digunakan adalah convenience sampling. Alat ukur yang digunakan dalam penelitian ini berasal dari proyek penelitian Children's Worlds (www.isciweb.org), di mana penulis merupakan principal investigator penelitian internasional ini di Indonesia. Versi asli dari seluruh alat ukur adalah dalam Bahasa Inggris yang kemudian diadaptasi oleh peneliti untuk dapat digunakan di Indonesia, dengan mengacu pada proses yang dijelaskan oleh Borualogo et al. (2019). SWB diukur menggunakan Children's Worlds Subjective Well-Being (CW-SWBS5) yang terdiri dari lima pertanyaan, yaitu: 1) "Saya menikmati kehidupan saya"; 2) "Kehidupan saya berjalan dengan baik"; (3) "Saya memiliki kehidupan yang baik"; (4) "Hal-hal yang terjadi dalam kehidupan saya sangat baik"; dan (5) "Saya senang/bahagia dengan kehidupan saya" (Borualogo \& Casas, 2019). Pilihan jawaban terdiri dari 11point scale dari 0 (sama sekali tidak setuju) hingga 10 (benar-benar setuju). Untuk analisis, kelima pertanyaan ini dikalkulasikan menjadi skor SWB dan dikonversikan menjadi skala 100 (Borualogo \& Casas, 2021a, 2021b) sehingga dapat dibandingkan dengan nilai rerata SWB berdasarkan teori Cummins (2014). Alat ukur CW-SWBS5 ini menunjukkan indeks kecocokan yang dapat digunakan di 
Indonesia. Indeks kecocokan dengan menggunakan sampel representatif usia 10 tahun adalah $\chi^{2}=$ $75.17, d f=5, p=.000$, comparative fit index $(\mathrm{CFI})=.995$ dan root mean square error of approximation $($ RMSEA $)=.043(.035-.052)$, dan untuk usia 12 tahun adalah $\chi^{2}=93.79, d f=5, p=.000$, CFI $=.995$ dan RMSEA $=.047$ (.039 - .056) (Borualogo \& Casas, 2019). Nilai reliabilitas alpha Cronbach alat ukur ini pada sampel penelitian ini adalah .974.

Persepsi mengenai relasi anak dengan teman diukur melalui empat pertanyaan dari alat ukur relasi dengan teman dari Children's Worlds (Rees et al., 2020), yaitu: 1) "Saya memiliki cukup teman"; 2) "Teman-teman saya biasanya baik kepada saya"; 3) "Saya akur dengan teman-teman saya"; dan 4) "Ketika saya memiliki masalah, ada teman yang memberi dukungan kepada saya." Nilai reliabilitas alpha Cronbach alat ukur ini pada sampel penelitian ini adalah .862. Untuk mengetahui mode komunikasi yang digunakan oleh anak, disajikan sejumlah mode komunikasi dan anak diminta untuk menjawab apakah mereka menggunakan atau tidak menggunakan mode komunikasi tersebut. Adapun mode komunikasi yang disajikan dalam daftar pertanyaan adalah voice call, video call, WhatsApp, Instagram, Facebook, LINE, Twitter, Telegram, Discord, TikTok, Zoom, Snapchat, Webex, Google Meet, online games, bermain di sekitar rumah bersama teman-teman, dan bertemu tatap muka dengan teman. Daftar mode komunikasi ini disusun berdasarkan hasil penelitian awal yang dilakukan pada tahun pertama pandemi COVID-19 (Borualogo \& Casas, 2021a). Hasil penelitian awal menunjukkan bahwa daftar mode komunikasi tersebut adalah yang paling umum digunakan oleh anak dan remaja di masa COVID-19.

Data dianalisis menggunakan regresi linier berganda, analisis deskriptif bivariat, dan analisis deskriptif menggunakan ANOVA. Untuk menentukan variabel yang akan disertakan dalam analisis regresi, dilakukan analisis bivariat dengan menghitung signifikansi perbedaan menggunakan chi-square dan effect size (Tabel 2). Hanya hasil yang signifikan pada analisis bivariat yang disertakan sebagai variabel bebas pada analisis regresi berganda. Model regresi linear berganda dianalisis dengan menyertakan jenis kelamin dan kelompok usia sebagai variabel kontrol (Tabel 3). Analisis deskriptif menggunakan ANOVA menyajikan skor SWB untuk tiap jawaban dari variabel bebas (Tabel 4). Analisis statistik dilakukan menggunakan SPSS versi 25.

\section{HASIL DAN PEMBAHASAN}

Komposisi partisipan penelitian seperti disajikan pada Tabel 1 memperlihatkan bahwa 54.9\% partisipan adalah laki-laki, dan 45.8\% partisipan adalah kelompok usia Sekolah Menengah Atas (SMA).

Tabel 1. Karakteristik sampel

\begin{tabular}{lcccccc}
\hline Kelompok usia & \multicolumn{2}{c}{ Perempuan } & \multicolumn{2}{c}{ Laki-laki } & \multicolumn{2}{c}{ Total } \\
\cline { 2 - 7 } & $n$ & $\%$ & $n$ & $\%$ & $n$ & $\%$ \\
\hline Sekolah Dasar & 23 & 1.4 & 198 & 11.9 & 221 & 13.3 \\
Sekolah Menengah Pertama & 289 & 17.4 & 388 & 23.4 & 677 & 40.9 \\
Sekolah Menengah Atas & 435 & 26.3 & 324 & 19.6 & 759 & 45.8 \\
Total & 747 & 45.1 & 910 & 54.9 & 1,657 & 100 \\
\hline
\end{tabular}

Hasil menunjukkan sebanyak $32.4 \%$ partisipan menyetujui bahwa mereka memiliki cukup teman, $41.7 \%$ menyetujui bahwa teman biasanya baik terhadap mereka, dan $39.6 \%$ menyetujui bahwa teman akan memberikan dukungan ketika partisipan memiliki masalah (Tabel 2). Pertanyaan mengenai ukur dengan teman-teman tidak menunjukkan perbedaan signifikan antara partisipan perempuan dan laki-laki sehingga tidak dituliskan dalam Tabel 2 dan tidak disertakan pada analisis regresi berganda. Lebih banyak partisipan laki-laki dibandingkan partisipan perempuan yang menyatakan sangat setuju bahwa mereka memiliki cukup teman, teman biasanya baik, dan memberikan dukungan ketika mereka memiliki masalah.

Perbedaan signifikan antara partisipan perempuan dan laki-laki dalam menggunakan tiap mode komunikasi di masa pandemi juga ditunjukkan pada Tabel 2. Mode komunikasi yang paling banyak digunakan adalah WhatsApp. Persentase partisipan perempuan dan laki-laki yang menggunakan voice call sebagai mode komunikasi dengan teman relatif sama jumlahnya. Lebih banyak perempuan yang menggunakan video call, Instagram, LINE, Twitter, Telegram, TikTok, Zoom, Snapchat, dan Google 
Meet dibandingkan laki-laki. Sementara itu, partisipan laki-laki lebih banyak menggunakan Facebook, Discord, online games, bermain di sekitar rumah, dan bertemu langsung dibandingkan perempuan.

Tabel 2. Perbedaan Signifikan antara Partisipan Perempuan dan Laki-Laki dalam Mengevaluasi Situasi Relasi dengan Teman selama Masa Tahun Kedua Pandemi

\begin{tabular}{|c|c|c|c|c|c|c|c|c|c|c|}
\hline & \multicolumn{3}{|c|}{ Perempuan } & \multicolumn{3}{|c|}{ Laki-laki } & \multicolumn{2}{|c|}{ Total } & \multirow{2}{*}{$\begin{array}{c}\text { Chi- } \\
\text { Square }\end{array}$} & \multirow{2}{*}{$\begin{array}{c}\text { Crame } \\
r \text { 's V }\end{array}$} \\
\hline & $n$ & $\%$ & $\begin{array}{c}\text { Resi- } \\
\text { dual }\end{array}$ & $n$ & $\%$ & $\begin{array}{r}\text { Resi- } \\
\text { dual }\end{array}$ & $n$ & $\%$ & & \\
\hline & \multicolumn{10}{|c|}{ Memiliki cukup teman } \\
\hline Sangat tidak setuju & 72 & 4.4 & 3.2 & 37 & 2.3 & -2.9 & 109 & 6.7 & & \\
\hline Agak setuju & 142 & 8.7 & 3.5 & 91 & 5.6 & -3.2 & 233 & 14.3 & & \\
\hline Cukup setuju & 179 & 11.0 & 1.7 & 169 & 10.4 & -1.5 & 348 & 21.4 & & \\
\hline Setuju & 205 & 12.6 & -2.2 & 322 & 19.8 & 2.0 & 527 & 32.4 & & \\
\hline Sangat setuju & 140 & 8.6 & -3.3 & 268 & 16.5 & 3.0 & 408 & 25.1 & & \\
\hline \multirow[t]{2}{*}{ Total } & 738 & 45.4 & & 887 & 54.6 & & 1,625 & 100 & $75.796 * *$ & .216 \\
\hline & \multicolumn{10}{|c|}{ Teman-teman saya baik } \\
\hline Sangat tidak setuju & 19 & 1.2 & 0.8 & 16 & 1.0 & -0.7 & 35 & 2.1 & & \\
\hline Agak setuju & 116 & 7.1 & 2.9 & 81 & 5.0 & -2.6 & 197 & 12.1 & & \\
\hline Cukup setuju & 181 & 11.1 & 0.8 & 197 & 12.1 & -0.7 & 378 & 23.2 & & \\
\hline Setuju & 283 & 17.3 & -1.4 & 398 & 24.4 & 1.3 & 681 & 41.7 & & \\
\hline Sangat setuju & 139 & 8.5 & -1.2 & 202 & 12.4 & 1.1 & 341 & 20.9 & & \\
\hline \multirow[t]{2}{*}{ Total } & 738 & 45.2 & & 894 & 54.8 & & 1,632 & 100 & $23.515 * *$ & .120 \\
\hline & \multicolumn{10}{|c|}{ Teman mendukung } \\
\hline Sangat tidak setuju & 42 & 2.6 & 1.4 & 33 & 2.0 & -1.3 & 75 & 4.6 & & \\
\hline Agak setuju & 102 & 6.3 & 1.7 & 89 & 5.5 & -1.6 & 191 & 11.8 & & \\
\hline Cukup setuju & 152 & 9.4 & -0.3 & 194 & 11.9 & 0.3 & 346 & 21.3 & & \\
\hline Setuju & 265 & 16.3 & -1.5 & 378 & 23.3 & 1.3 & 643 & 39.6 & & \\
\hline Sangat setuju & 171 & 10.5 & 0.4 & 198 & 12.2 & -0.3 & 369 & 22.7 & & \\
\hline \multirow[t]{2}{*}{ Total } & 732 & 45.1 & & 892 & 54.9 & & 1,624 & 100 & $13.262 *$ & .090 \\
\hline & \multicolumn{10}{|c|}{ Komunikasi melalui voice call } \\
\hline $\mathrm{Ya}$ & 436 & 26.3 & 2.0 & 442 & 26.7 & -1.8 & 878 & 53.0 & & \\
\hline Tidak & 311 & 18.8 & -2.1 & 468 & 28.2 & 1.9 & 779 & 47.0 & & \\
\hline \multirow[t]{2}{*}{ Total } & 747 & 45.1 & & 910 & 54.9 & & 1,657 & 100 & $15.801 * *$ & .098 \\
\hline & \multicolumn{10}{|c|}{ Komunikasi menggunakan video call } \\
\hline $\mathrm{Ya}$ & 423 & 25.5 & 3.0 & 388 & 23.4 & -2.7 & 811 & 48.9 & & \\
\hline Tidak & 324 & 19.6 & -2.9 & 522 & 31.5 & 2.7 & 846 & 51.1 & & \\
\hline \multirow[t]{2}{*}{ Total } & 747 & 45.1 & & 910 & 54.9 & & 1,657 & 100 & $32.127 * *$ & .139 \\
\hline & \multicolumn{10}{|c|}{ Komunikasi melalui WhatsApp } \\
\hline Ya & 724 & 43.7 & 0.7 & 841 & 50.8 & -0.6 & 1.565 & 94.4 & & \\
\hline Tidak & 23 & 1.4 & -2.9 & 69 & 4.2 & 2.6 & 92 & 5.6 & & \\
\hline \multirow[t]{2}{*}{ Total } & 747 & 45.1 & & 910 & 54.9 & & 1,657 & 100 & $15.866^{* *}$ & .098 \\
\hline & \multicolumn{10}{|c|}{ Instagram } \\
\hline $\mathrm{Ya}$ & 503 & 30.4 & 3.7 & 444 & 26.8 & -3.3 & 947 & 57.2 & & \\
\hline Tidak & 244 & 14.7 & -4.3 & 466 & 28.1 & 3.9 & 710 & 42.8 & & \\
\hline Total & 747 & 45.1 & & 910 & 54.9 & & 1,657 & 100 & $57.613 * *$ & .186 \\
\hline & & & & & Fac & bok & & & & \\
\hline $\mathrm{Ya}$ & 132 & 8.0 & -2.7 & 239 & 14.4 & 2.5 & 371 & 22.4 & & \\
\hline Tidak & 615 & 37.1 & 1.5 & 671 & 40.5 & -1.3 & 1.286 & 77.6 & & \\
\hline Total & 747 & 45.1 & & 910 & 54.9 & & 1,657 & 100 & $17.433 * *$ & .103 \\
\hline & & & & & & & & & & \\
\hline $\mathrm{Ya}$ & 210 & 12.7 & 2.5 & 181 & 10.9 & -2.3 & 391 & 23.6 & & \\
\hline Tidak & 537 & 32.4 & -1.4 & 729 & 44.0 & 1.3 & 1.266 & 76.4 & & \\
\hline Total & 747 & 45.1 & & 910 & 54.9 & & 1,657 & 100 & $15.384 * *$ & .096 \\
\hline & & & & & & & & & & \\
\hline $\mathrm{Ya}$ & 246 & 14.8 & 4.7 & 159 & 9.6 & -4.3 & 405 & 24.4 & & \\
\hline Tidak & 501 & 30.2 & -2.7 & 751 & 45.3 & 2.4 & 1,252 & 75.6 & & \\
\hline Total & 747 & 45.1 & & 910 & 54.9 & & 1,657 & 100 & $53.088 * *$ & .179 \\
\hline
\end{tabular}




\begin{tabular}{|c|c|c|c|c|c|c|c|c|c|c|}
\hline \multirow[b]{2}{*}{$\mathrm{Ya}$} & \multicolumn{10}{|c|}{ Telegram } \\
\hline & 216 & 13.0 & 4.9 & 128 & 7.7 & -4.4 & 344 & 20.8 & & \\
\hline Tidak & 531 & 32.0 & -2.5 & 782 & 47.2 & 2.3 & 1,313 & 79.2 & & \\
\hline \multirow[t]{2}{*}{ Total } & 747 & 45.1 & & 910 & 54.9 & & 1,657 & 100 & $54.992 * *$ & .182 \\
\hline & \multicolumn{10}{|c|}{ Discord } \\
\hline $\mathrm{Ya}$ & 52 & 3.1 & -2.3 & 107 & 6.5 & 2.1 & 159 & 9.6 & & \\
\hline Tidak & 695 & 41.9 & 0.8 & 803 & 48.5 & -0.7 & 1,498 & 90.4 & & \\
\hline \multirow[t]{2}{*}{ Total } & 747 & 45.1 & & 910 & 54.9 & & 1,657 & 100 & $10.882 * *$ & .081 \\
\hline & \multicolumn{10}{|c|}{ TikTok } \\
\hline $\mathrm{Ya}$ & 228 & 13.8 & 4.2 & 155 & 9.4 & -3.8 & 383 & 23.1 & & \\
\hline Tidak & 519 & 31.3 & -2.3 & 755 & 45.6 & 2.1 & 1,274 & 76.9 & & \\
\hline \multirow[t]{2}{*}{ Total } & 747 & 45.1 & & 910 & 54.9 & & 1,657 & 100 & $42.003 * *$ & .159 \\
\hline & \multicolumn{10}{|c|}{ Zoom } \\
\hline $\mathrm{Ya}$ & 243 & 14.7 & 2.6 & 213 & 12.9 & -2.4 & 456 & 27.5 & & \\
\hline Tidak & 504 & 30.4 & -1.6 & 697 & 42.1 & 1.5 & 1,201 & 72.5 & & \\
\hline \multirow[t]{2}{*}{ Total } & 747 & 45.1 & & 910 & 54.9 & & 1,657 & 100 & $17.120 * *$ & .102 \\
\hline & \multicolumn{10}{|c|}{ Snapchat } \\
\hline $\mathrm{Ya}$ & 39 & 2.4 & 3.6 & 10 & 0.6 & -3.3 & 49 & 3.0 & & \\
\hline Tidak & 708 & 42.7 & -0.6 & 900 & 54.3 & 0.6 & 1,608 & 97.0 & & \\
\hline \multirow[t]{2}{*}{ Total } & 747 & 45.1 & & 910 & 54.9 & & 1,657 & 100 & $24.289 * *$ & .121 \\
\hline & \multicolumn{10}{|c|}{ Google Meet } \\
\hline $\mathrm{Ya}$ & 203 & 12.3 & 1.9 & 190 & 11.5 & -1.8 & 393 & 23.7 & & \\
\hline Tidak & 544 & 32.8 & -1.1 & 720 & 43.5 & 1.0 & 1,264 & 76.3 & & \\
\hline \multirow[t]{2}{*}{ Total } & 747 & 45.1 & & 910 & 54.9 & & 1,657 & 100 & $8.989 * *$ & .074 \\
\hline & \multicolumn{10}{|c|}{ Online games } \\
\hline $\mathrm{Ya}$ & 108 & 6.5 & -8.6 & 427 & 25.8 & 7.8 & 535 & 32.3 & & \\
\hline Tidak & 639 & 38.6 & 5.9 & 483 & 29.1 & -5.4 & 1,122 & 67.7 & & \\
\hline \multirow[t]{2}{*}{ Total } & 747 & 45.1 & & 910 & 54.9 & & 1,657 & 100 & $19.777 * *$ & .345 \\
\hline & \multicolumn{10}{|c|}{ Bermain di sekitar rumah dengan teman } \\
\hline $\mathrm{Ya}$ & 239 & 14.4 & -2.3 & 375 & 22.6 & 2.1 & 614 & 37.1 & & \\
\hline Tidak & 508 & 30.7 & 1.7 & 535 & 32.3 & -1.6 & 1,043 & 62.9 & & \\
\hline \multirow[t]{2}{*}{ Total } & 747 & 45.1 & & 910 & 54.9 & & 1,657 & 100 & $14.933 * *$ & .095 \\
\hline & \multicolumn{10}{|c|}{ Bertemu langsung } \\
\hline Ya & 429 & 25.9 & 1.4 & 460 & 27.8 & -1.3 & 889 & 53.7 & & \\
\hline Tidak & 318 & 19.2 & -1.5 & 450 & 27.2 & 1.4 & 768 & 46.3 & & \\
\hline Total & 747 & 45.1 & & 910 & 54.9 & & 1,657 & 100 & $7.810^{* *}$ & .069 \\
\hline
\end{tabular}

Ket.: *signifikan pada $p<.05 ; * *$ signifikan pada $p<.01$

Jenis kelamin dan kelompok usia sebagai kontrol variabel tidak memberikan kontribusi signifikan terhadap SWB pada model regresi relasi dengan teman sebaya seperti dijelaskan pada Tabel 3. Dengan demikian, pengujian regresi linear hanya dilakukan pada pooled sample dan tidak dilakukan pengujian secara khusus berdasarkan jenis kelamin dan kelompok usia.

Tabel 3. Model Regresi dari Berbagai Variabel mengenai Relasi dengan Teman pada Subjective Well-Being (Diukur Menggunakan CW-SWBS sebagai Indikator)

\begin{tabular}{|c|c|c|c|c|c|c|c|}
\hline & \multirow[t]{2}{*}{ b } & \multirow[t]{2}{*}{ SE } & \multirow[t]{2}{*}{$\beta$} & \multirow[t]{2}{*}{$\mathrm{t}$} & \multirow[t]{2}{*}{$\mathrm{p}$} & \multicolumn{2}{|c|}{$\begin{array}{c}95 \% \text { Confidence } \\
\text { interval }\end{array}$} \\
\hline & & & & & & Lower & Upper \\
\hline Constant & 35.976 & 10.002 & & 3.597 & .000 & 16.358 & 55.594 \\
\hline Jenis kelamin & -1.596 & 1.298 & -.032 & -1.230 & .219 & -4.143 & .950 \\
\hline Kelompok usia & -.946 & .937 & -.026 & -1.010 & .313 & -2.785 & .892 \\
\hline Memiliki cukup teman & 4.560 & .659 & .217 & 6.917 & .000 & 3.267 & 5.853 \\
\hline Teman biasanya baik & 4.299 & .785 & .172 & 5.474 & .000 & 2.758 & 5.839 \\
\hline Teman akan mendukung & 2.589 & .689 & .113 & 3.755 & .000 & 1.237 & 3.941 \\
\hline Voice call & 3.903 & 1.389 & .078 & 2.811 & .005 & 1.179 & 6.627 \\
\hline Video call & -5.814 & 1.397 & -.116 & -4.162 & .000 & -8.554 & -3.074 \\
\hline WhatsApp & 1.027 & 2.584 & .009 & .398 & .691 & -4.041 & 6.095 \\
\hline Instagram & -4.671 & 1.312 & -.092 & -3.560 & .000 & -7.245 & -2.098 \\
\hline Facebook & 2.679 & 1.422 & .045 & 1.884 & .060 & -.111 & 5.469 \\
\hline LINE & .608 & 1.467 & .010 & .414 & .679 & -2.270 & 3.486 \\
\hline
\end{tabular}




\begin{tabular}{lccccccc}
\hline Twitter & 2.994 & 1.472 & .052 & 2.034 & .042 & .107 & 5.881 \\
Telegram & 2.805 & 1.540 & .045 & 1.822 & .069 & -.216 & 5.826 \\
Discord & -1.777 & 2.012 & -.021 & -.883 & .377 & -5.724 & 2.169 \\
TikTok & 1.338 & 1.426 & .023 & .939 & .348 & -1.458 & 4.135 \\
Zoom & .912 & 1.515 & .016 & .602 & .547 & -2.061 & 3.885 \\
Snapchat & -1.150 & 3.384 & -.008 & -.340 & .734 & -7.787 & 5.487 \\
Google Meet & -1.168 & 1.556 & -.020 & -.751 & .453 & -4.219 & 1.883 \\
Online games & .624 & 1.351 & .012 & .462 & .644 & -2.026 & 3.275 \\
Bermain di sekitar rumah & -1.939 & 1.292 & -.037 & -1.501 & .134 & -4.472 & .595 \\
bersama teman & & & & & & & \\
Bertemu dengan teman secara & -2.212 & 1.226 & -.044 & -1.803 & .072 & -4.617 & .194 \\
tatap muka & & & & & & &
\end{tabular}

Ket.: $p=.000 ; F=23.159 ; d f 1=21 ; d f 2=1565 ;$ adjusted $R^{2}=.227$

Model yang disajikan pada Tabel 3 menyertakan 1,565 kasus dan dapat menjelaskan 22.7\% variabilitas dari variabel terikat SWB yang diukur menggunakan CW-SWBS. Persepsi partisipan bahwa mereka memiliki cukup teman, teman biasanya baik, dan ada teman yang memberikan dukungan ketika partisipan memiliki masalah, menunjukkan signifikansi positif terhadap SWB partisipan. Berbagai penelitian yang dilakukan sebelum masa pandemi COVID-19 menunjukkan bahwa pertemanan merupakan faktor signifikan bagi kebahagiaan anak dan remaja (Bagwell et al., 2015; Goswami, 2012; Savahl et al., 2020), meliputi memiliki cukup teman, mendapatkan dukungan dari teman ketika berada dalam kesulitan, kualitas pertemanan, dan karakteristik pertemanan. Hasil penelitian ini yang dilakukan pada tahun kedua pandemi COVID-19 juga menunjukkan hasil yang sejalan dengan penelitian tersebut.

Model regresi yang disajikan di Tabel 3 menunjukkan bahwa memiliki cukup teman di masa tahun kedua pandemi COVID-19 memberikan sumbangan efektif terbesar bagi SWB anak dan remaja $(\beta=.217)$. Memiliki cukup teman dapat menunjukkan interaksi yang berbeda antara anak dan remaja dengan orang yang mereka nilai sebagai teman dan dengan orang yang mereka nilai bukan sebagai teman. Pertemanan dapat ditunjukkan melalui relasi yang bersifat setara di mana seorang anak atau remaja tertarik pada anak atau remaja lainnya yang juga memiliki ketertarikan terhadap mereka. Menurut Bagwell et al. (2015), memiliki cukup teman memberikan kesempatan kepada anak dan remaja untuk menunjukkan saling keterikatan yang positif, berbagi cerita, dan tertawa bersama. Pada tahun kedua masa pandemi, memiliki cukup teman menjadi semakin penting karena anak mengalami keterbatasan kesempatan berinteraksi sosial. Dapat dibayangkan jika anak tidak memiliki cukup teman di masa pembatasan jarak sosial, mereka akan benar-benar tidak memiliki kesempatan untuk menjalin relasi sosial yang hangat.

Teman biasanya baik $(\beta=.172)$ dan teman akan memberikan dukungan di saat anak dan remaja memiliki masalah $(\beta=.113)$ juga memprediksi SWB anak dan remaja pada tahun kedua masa pandemi seperti dijelaskan pada model regresi di Tabel 3. Teman yang dinilai baik dan memberikan dukungan di saat dibutuhkan menunjukkan kualitas pertemanan yang positif. Bagwell et al. (2015) menjelaskan fitur positif dari kualitas pertemanan, yaitu persahabatan, kedekatan, memberikan bantuan di saat dibutuhkan, menunjukkan keakraban, dan loyalitas. Di sisi lain, Tabel 4 memperlihatkan partisipan yang menyatakan sangat setuju memiliki cukup teman, sangat setuju teman biasanya baik, dan sangat setuju teman akan mendukung ketika partisipan memiliki masalah, secara signifikan menunjukkan nilai rerata SWB yang paling tinggi. Sementara itu, partisipan yang menyatakan sangat tidak setuju pada ketiga pernyataan mengenai relasi dengan teman tersebut menunjukkan nilai rerata SWB yang paling rendah.

Jika dalam situasi sebelum pandemi COVID-19 relasi pertemanan dilakukan dalam interaksi langsung tatap muka, pada situasi pandemi hal tersebut tidak dapat dilakukan. Penelitian yang dilakukan oleh Borualogo dan Casas (2021a) pada tahun pertama COVID-19 menunjukkan bahwa anak dan remaja melaporkan ketidakpuasan atas relasinya dengan teman karena tidak dapat bertemu tatap muka. Sebagai alternatif pengganti relasi sosial tatap muka adalah dengan menggunakan mode komunikasi berbasis internet. Model yang disajikan pada Tabel 3 juga menunjukkan bahwa penggunaan mode komunikasi voice call, video call, Instagram, dan Twitter dapat memprediksi SWB penggunanya. Partisipan yang tidak menggunakan voice call $(n=779 ; 47 \%)$ dan Twitter $(n=1,252 ; 75.6 \%)$ diprediksi menunjukkan SWB yang lebih tinggi dengan selisih 0.078 untuk voice call dan 0.052 untuk Twitter. Sebanyak $156(20 \%)$ partisipan yang tidak menggunakan voice call adalah pengguna video call, dan 
sebanyak 343 (44\%) adalah pengguna Instagram. Sementara itu, sebanyak 565 partisipan (45.1\%) yang tidak menggunakan Twitter adalah pengguna video call, dan sebanyak 624 (49.8\%) adalah pengguna Instagram. Hasil ini menunjukkan bahwa lebih dari $20 \%$ partisipan yang tidak menggunakan voice call ataupun Twitter, adalah pengguna video call dan Instagram. Sementara itu, partisipan yang menggunakan video call dan Instagram diprediksi menunjukkan SWB yang lebih tinggi dengan selisih .116 untuk video call dan .092 untuk Instagram.

Tabel 4. Skor SWB untuk Tiap Jawaban pada Variabel Bebas

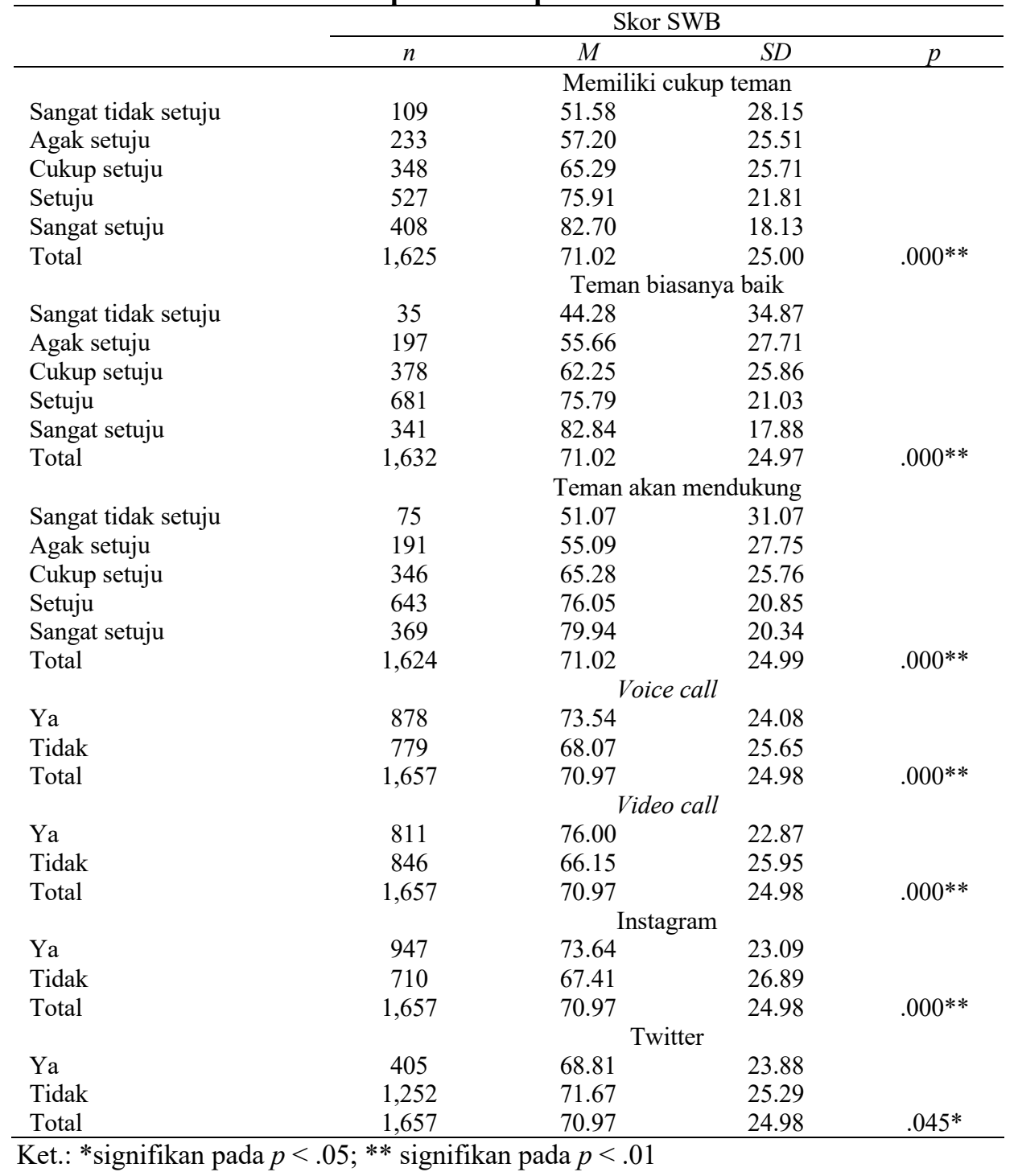

Tabel 4 memperlihatkan bahwa partisipan yang menggunakan video call $(M=76.00)$ dan Instagram $(M=73.64)$ menunjukkan nilai rerata SWB yang lebih tinggi dibandingkan yang tidak menggunakan $(M=66.15$ untuk video call dan $M=67.41$ untuk Instagram). Fitur video call memberikan kesempatan kepada anak dan remaja untuk dapat bertatap muka secara daring dengan teman-temannya sehingga memenuhi kebutuhan interaksi mereka dan memprediksi SWB mereka. Demikian pula dengan Instagram yang memiliki fitur berbagi foto, instastory, dan video call sehingga memungkinkan bagi anak dan remaja untuk melihat aktivitas temannya maupun melakukan percakapan tatap muka daring melalui video. Hasil ini sejalan dengan hasil penelitian yang dilakukan oleh Hanley et al. (2019) yang menunjukkan bahwa penggunaan Instagram dapat memberikan keuntungan bagi pengguna aktif karena memberikan kontribusi bagi afek positif pengguna aktif Instagram (Hanley et al., 2019). 
Sementara itu, partisipan yang tidak menggunakan Twitter $(M=71.67)$ menunjukkan nilai rerata SWB yang lebih tinggi dibandingkan yang menggunakan Twitter $(M=68.81)$. Jumlah partisipan yang menggunakan voice call $(n=878)$ lebih banyak daripada jumlah partisipan yang tidak menggunakan voice call $(n=779)$. Walaupun nilai rerata SWB secara signifikan lebih tinggi pada kelompok yang menggunakan voice call, namun dengan mengacu pada Tabel 3, model regresi memprediksi kelompok yang tidak menggunakan voice call akan menunjukkan skor SWB yang lebih tinggi. Hal ini terjadi karena kebutuhan anak adalah melakukan komunikasi tatap muka secara daring melalui video. Voice call tidak memiliki fitur percakapan tatap muka melalui video sehingga dipersepsi oleh anak sebagai kurang memberikan kontribusi bagi SWB mereka. Demikian pula dengan Twitter yang hanya memiliki fitur berbagi informasi melalui pesan pendek sehingga tidak dapat memenuhi kebutuhan anak untuk berinteraksi tatap muka melalui video secara daring.

Walaupun studi ini tidak menguji kontribusi jenis kelamin terhadap SWB karena model regresinya tidak menunjukkan signifikansi berdasarkan perbedaan jenis kelamin, namun temuan dari Fioravanti et al. (2020) menarik untuk dicermati. Studi yang dilakukan oleh Fioravanti et al. (2020) menunjukkan bahwa perempuan yang berhenti menggunakan Instagram menunjukkan peningkatan signifikan pada kepuasan hidup dan afek positif dibandingkan perempuan yang tetap menggunakan Instagram. Hal ini terjadi karena perempuan yang berhenti menggunakan Instagram, tidak lagi mengalami terpapar umpan balik evaluatif secara langsung mengenai citra diri mereka di Instagram, baik terkait penampilan, kebiasaan, maupun opini mengenai diri mereka, sehingga meningkatkan kepuasan hidup mereka. Berdasarkan Tabel 2, hasil studi ini menunjukkan bahwa secara signifikan lebih banyak perempuan yang menggunakan Instagram dibandingkan laki-laki. Sehingga meskipun model regresi tidak dapat menguji kontribusi jenis kelamin terhadap SWB pengguna mode komunikasi tertentu, namun hasil penelitian Fioravanti et al. (2020) dapat menjadi peringatan bagi anak dan remaja yang terlalu aktif menggunakan Instagram.

Terkait penggunaan sosial media sebagai sarana berkomunikasi, hasil yang ditunjukkan pada penelitian ini sejalan dengan studi longitudinal yang dilakukan oleh Bae (2019) yang menunjukkan bahwa penggunaan telepon genggam pada tahun pertama studi untuk berkomunikasi dengan teman memberikan pengaruh positif terhadap SWB partisipan penelitiannya yang merupakan siswa Sekolah Dasar dengan rata-rata usia 10.98 tahun. Penggunaan telepon genggam yang terkoneksi dengan media sosial pada masa tahun kedua pandemi dapat membantu anak dan remaja untuk tetap membangun keterhubungan sosial dengan teman pada saat pembatasan jarak sosial sehingga berkontribusi pada SWB anak dan remaja seperti ditunjukkan oleh model regresi di Tabel 3.

Namun, hasil studi longitudinal yang dilakukan oleh Bae (2019) juga menunjukkan bahwa penggunaan telepon genggam pada tahun-tahun selanjutnya setelah studi pada tahun pertama dilakukan, tidak memberikan pengaruh terhadap SWB sepanjang waktu. Menurut Bae (2019), hal ini ditentukan oleh ketersediaan sumber daya melalui jejaring sosial di luar jaringan internet yang bersifat resiprokal. Jika mengacu pada model regresi dalam Tabel 3 yang menunjukkan sumbangan efektif relasi pertemanan terhadap SWB yang berada pada kisaran di bawah 10\%, dapat diindikasikan adanya faktor lain yang memberikan kontribusi lebih besar terhadap SWB anak dan remaja pada masa tahun kedua pandemi ini. Berdasarkan hal tersebut, anak dan remaja tetap perlu menjalin relasi positif dengan temantemannya di luar jaringan. Anak dan remaja tetap butuh menjalin keterhubungan dengan orang-orang terdekatnya, termasuk dengan teman, melalui interaksi sosial tatap muka di luar jaringan. Pernyataan ini juga mendukung temuan pada sebuah studi di Jepang yang dilakukan oleh Ishii (2017) yang menyatakan bahwa komunikasi melalui sosial media secara signifikan berkorelasi dengan SWB dan dimediasi oleh jumlah teman di dalam dan luar jaringan. Studi yang dilakukan oleh Dimmock et al. (2021) juga menjelaskan bahwa kepuasan dalam relasi sosial secara signifikan memediasi hubungan antara interaksi berbasis teknologi dengan well-being di masa pandemi.

Meskipun model regresi yang disajikan pada Tabel 3 menunjukkan mode komunikasi yang dapat memprediksi SWB anak dan remaja, namun penggunaannya tetap perlu disupervisi oleh orang tua. Sejumlah penelitian menunjukkan bahwa penggunaan sosial media secara berlebihan dapat menimbulkan konsekuensi merusak, seperti penurunan kepuasan hidup, peningkatan afek negatif, dan peningkatan rasa kesepian (Vally \& D'Souza, 2019). Hasil penelitian Vally dan D'Souza (2019) menguatkan urgensi adanya supervisi dari orang tua dalam menggunakan sosial media. 
Pada saat ini, interaksi sosial melalui media komunikasi berbasis daring merupakan salah satu alternatif terbaik di masa pandemi COVID-19 untuk tetap menjaga SWB anak dan remaja. Keterhubungan sosial menggunakan media komunikasi berbasis daring dapat menurunkan perasaan terisolasi pada anak dan remaja yang menjalani pembatasan jarak sosial di masa pandemi COVID-19 dan secara signifikan berkontribusi bagi SWB anak dan remaja. Namun, hasil penelitian Children's Worlds menunjukkan hanya $46 \%$ anak-anak yang melaporkan bahwa mereka memiliki akses internet (Rees et al., 2020). Dengan demikian, hal ini perlu kiranya menjadi perhatian bagi para pengambil keputusan untuk dapat membantu penyediaan akses internet yang lebih luas jangkauannya. Hal ini tidak hanya untuk keperluan komunikasi anak yang berkontribusi signifikan terhadap SWB mereka, tetapi juga bagi keperluan PJJ.

Penelitian ini memiliki beberapa keterbatasan. Sampel convenience yang hanya berasal dari wilayah Jawa Barat menyebabkan hasil penelitian ini tidak dapat digeneralisasi pada anak dan remaja Indonesia. Selain itu, penelitian ini terbatas pada kelompok anak dan remaja yang memiliki alat komunikasi berbasis internet. Oleh karena itu, penelitian ini belum dapat menjelaskan relasi dengan teman dan SWB anak dan remaja yang tidak memiliki alat komunikasi berbasis internet dan hanya mengandalkan relasi tatap muka di masa pandemi COVID-19. Dengan demikian, penelitian selanjutnya dapat menyertakan anak dan remaja yang tidak memiliki alat komunikasi berbasis internet untuk dikaji relasinya dengan teman di masa pandemi COVID-19.

\section{SIMPULAN}

Hasil penelitian menunjukkan bahwa relasi dengan teman yang ditunjukkan melalui memiliki cukup teman, teman biasanya baik, dan teman akan memberikan dukungan ketika dibutuhkan, secara signifikan memberikan kontribusi positif terhadap SWB anak dan remaja di masa tahun kedua pandemi COVID-19. Penggunaan mode komunikasi tertentu berbasis daring juga dapat memprediksi SWB anak dan remaja yang menggunakannya untuk berinteraksi dengan teman. Anak dan remaja yang menggunakan mode komunikasi berbasis daring dengan fitur video menunjukkan SWB yang lebih tinggi dibandingkan anak dan remaja yang menggunakan mode komunikasi berbasis daring tanpa fitur video. Dikarenakan komunikasi berbasis daring adalah salah satu alternatif terbaik di masa pandemi untuk digunakan oleh anak dan remaja dalam berinteraksi sosial, maka diharapkan orang tua dapat memberikan kesempatan kepada anak untuk menggunakan mode komunikasi berbasis daring tersebut dengan tetap melakukan supervisi terhadap anak. Kepada para pengambil keputusan, hendaknya dapat menyediakan akses internet yang lebih luas guna kemudahan komunikasi berbasis daring agar dapat membantu anak dan remaja tetap menjalin relasi sosial dan mempertahankan SWB mereka.

\section{UCAPAN TERIMA KASIH}

Peneliti menyampaikan terima kasih kepada orang tua yang telah memberikan izin kepada anakanaknya untuk menjadi partisipan penelitian ini. Peneliti juga berterima kasih kepada anak dan remaja yang bersedia berpartisipasi aktif dalam penelitian ini.

\section{DAFTAR PUSTAKA}

Bae, S. M. (2019). The relationship between smartphone use for communication, social capital, and subjective well-being in Korean adolescents: Verification using multiple latent growth modelling. Children and Youth Services Review, 96, 93-99. https://doi.org/10.1016/j.childyouth.2018.11.032

Bagwell, C. L., Kochel, K. P., \& Schmidt, M. E. (2015). Friendship and happiness in adolescence. In M. Demir. (Eds)., Friendship and happiness (pp. 99-116). Springer. https://doi.org/10.1007/97894-017-9603-3_6

Borualogo, I. S., \& Casas, F. (2019). Adaptation and validation of the Children's Worlds Subjective Well-Being Scale (CW-SWBS) in Indonesia. Jurnal Psikologi, 46(2), 102-116. https://doi.org/10.22146/jpsi.38995 
Borualogo, I. S., \& Casas, F. (2021a). Children and adolescents' report on their quality of life during the COVID-19 pandemic. Psikohumaniora, 6(2), 153-170. https://doi.org/10.21580/pjpp.v6i2.8572

Borualogo, I. S., \& Casas, F. (2021b). Children's and adolescents'subjective well-being during the COVID-19 pandemic in Indonesia: two data collections [Manuscript under review]. Faculty of Psychology Universitas Islam Bandung, Doctoral Program on Education and Society, Faculty of Education and Social Science Universidad Andrés Bello, Chile, and Research Institute on Quality of Life, Universitat de Girona, Spain.

Borualogo, I. S., Gumilang, E., Mubarak, A., Khasanah, A. N., Wardati, M. A., Diantina, F. P., Permataputri, I., \& Casas, F. (2019). Process of translation of the Children's Worlds Subjective Well-Being Scale in Indonesia. Proceedings of the Social and Humaniora Research Symposium (SoRes 2018), 307, 180-183. https://doi.org/10.2991/sores-18.2019.42

Cheng, T. C., Kim, S., Koh, K. (2020). The impact of COVID-19 on subjective well-being: evidence from Singapore. In IZA Discussion Papers (No. 13702). https://econstor.eu/bitstream/10419/227229/1/dp13702.pdf

Diener, R., Oishi, S., \& Lucas, R. E. (2015). National accounts of subjective well-being. American Psychologist, 70(3), 234-242. https://doi.org/10.1037/a0038899

Dimmock, J., Krause, A. E., Rebar, A., \& Jackson, B. (2021). Relationships between social interactions, basic psychological need, and wellbeing during the COVID-19 pandemic. Psychology \& Health, https://doi.org/10.1080/08870446.2021.1921178

Ducharme, J. (2020, March 11). World Health Organization declares COVID-19 a 'pandemic'. Here's what that means. Time. https://time.com/5791661/who-coronavirus-pandemic-declaration/

Engel de Abreu, P. M. J., Neumann, S., Wealer, C., Abreu, N., Macedo, E. C., \& Kirsch, C. (2021). Subjective well-being of adolescents in Luxembourg, Germany, and Brazil during the COVID19 pandemic. Journal of Adolescent Health, 69(2), 211-218. https://doi.org/10.1016/j.jadohealth.2021.04.028

Fioravanti, G., Prostamo, A., \& Casale, S. (2020). Taking a short break from Instagram: the effects on subjective well-being. Cyberpsychology, Behavior, and Social Networking, 23(2), 107-112. https://doi.org/10.1089/cyber.2019.0400

Gandhawangi, S. (2021, April 14). Potensi depresi dan kecemasan kian tinggi saat pandemi COVID-19. Kompas. https://kompas.id/baca/kesehatan/2021/04/14/potensi-depresi-dan-kecemasan-kiantinggi-saat-pandemi-covid-19/

Goswami, H. (2012). Social relationships and children's subjective well-being. Social Indicators Research, 107, 575-588. https://doi.org/10.1007/s11205-011-9864-z

Hanley, S. M., Watt, S. E., \& Coventry, W. (2019). Taking a break: the effect of taking a vacation from Facebook and Instagram on subjective well-being. PloS ONE, 14(6). https://doi.org/10.1371/journal.pone.0217743

Ishii, K. (2017). Online communication with strong ties and subjective well-being in Japan. Computers in Human Behavior, 66, 129-137. https://doi.org/10.1016/j.chb.2016.09.033

Khor, S., Cummins, R. A., Fuller-Tyszkiewicz, M., Capic, T., Jona, C., Olsson, C. A., Hutchinson, D. (2020). Subjective wellbeing during COVID-19. http://www.acqol.com.au/uploads/surveys/survey-037-report.pdf

Kirsch, C., Engel de Abreu, P. M. J., Neumann, S., Wealer, C., Brazas, K., \& Hauffels, I. (2020). Subjective well-being and stay-at-home-experiences of children aged 6-16 during the first wave of the COVID-19 pandemic in Luxembourg: a report of the project COVID-Kids. University of Luxembourg. https://orbilu.uni.lu/bitstream/10993/45450/1/UNI_UNICEF_E.pdf

Marroquín, B., Vine, V., \& Morgan, R. (2020). Mental health during the COVID-19 pandemic: effects of stay-at-home policies, social distancing behavior, and social resources. Psychiatry Research, 293. https://doi.org/10.1016/j.psychres.2020.113419

Mínguez, A. M. (2020). Children's relationships and happiness: The role of family, friends and the school in four European countries. Journal of Happiness Studies: An Interdisciplinary Forum on Subjective Well-Being, 21(5), 1859-1878. https://doi.org/10.1007/s10902-019-00160-4

Mitra, R., Waygood, W. O. D., \& Fullan, J. (2021). Subjective well-being of Canadian children and youth during the COVID-19 pandemic: the role of the social and physical environment and 
heatlthy movement behaviours. Preventive Medicine Reports, 23. https://doi.org/10.101t/j.pmedr.2021.101404

Permatasari, D. (2021, Juli 31). Kebijakan COVID-19 dari PSBB hingga PPKM empat level. Kompaspedia. https://kompaspedia.kompas.id/baca/infografik/kronologi/kebijakan-covid-19dari-psbb-hingga-ppkm-empat-level

Prasetyani, Y. M. (2021, April 4). Internet sudah jadi napas baru kehidupan di tengah pandemi (A. D. Widiarni, Ed.). Kompas. https://nasional.kompas.com/read/2021/04/04/09020061/internetsudah-jadi-napas-baru-kehidupan-di-tengah-pandemi

Purwanto, A. (2021, Agustus 23). Ekonomi dunia di masa pandemi COVID-19: dari dampak hingga proyeksi pertumbuhan 2021-2022. Kompaspedia. https://kompaspedia.kompas.id/baca/paparantopik/ekonomi-dunia-di-masa-pandemi-covid-19-dari-dampak-hingga-proyeksi-pertumbuhan2021-2022

Rees, G. (2018). The association of childhood factors with children's subjective well-being and emotional and behavioural difficulties at 11 years old. Child Indicators Research, 11, 1107-1129. https://doi.org/10.1007/s12187-017-9479-2

Rees, G., Savahl, S., Lee, B. J., \& Casas, F. (Eds.). (2020). Children's view on their lives and well-being in 35 countries: a report on the Children's Worlds project, 2016-19. Children's Worlds Project (ISCWeB). https://isciweb.org/wp-content/uploads/2020/07/Childrens-Worlds-ComparativeReport-2020.pdf

Savahl, S., Adams, S., Florence, M., Casas, F., Mpilo, M., Isobell, D., \& Manuel, D. (2020). The relation between children's participation in daily activities, their engagement with family and friends, and subjective well-being. Child Indicators Research, 13, 1283-1312. https://doi.org/10.1007/s12187-019-09699-3

Savahl, S., Casas, F., \& Adams, S. (2021). The structure of children's subjective well-being. Frontiers in Psychology, 12. https://doi.org/10.3389/fpsyg.2021.650691

Vally, Z., \& D'Souza, C. G. (2019). Abstinence from social media use, subjective well-being, stress, and loneliness. Perspectives in Psychiatric Care, 55(4), 752-759. https://doi.org/10.1111/ppc.1243

Wantiknas (n.d.). Akses digital meningkat selama pandemi. https://www.wantiknas.go.id/id/berita/akses-digital-meningkat-selama-pademi

WHO. (2021). Update on coronavirus disease in Indonesia. https://who.intindonesia/news/novelcoronavirus 